\title{
Esplanade (Merdeka Square) of Medan City as a Symbol of Colonial City Civilization
}

\author{
$1^{\text {st }}$ Apriani Harahap ${ }^{1}, 2^{\text {nd }}$ Muhammad Rivai $^{2}, 3^{\text {rd }}$ Wira Fimansyah $^{3}, 4^{\text {th }}$ Novia Syahfitri, \\ $5^{\text {th }}$ Friska Bunga Aulina Sitorus, $6^{\text {th }}$ Khalisatun Zahra \\ \{aprianaiharahap@unimed.ac.id ${ }^{1}$, muhammadrivai@unimed.ac.id², wirafimansyah@unimed.ac.id ${ }^{3}$ \} \\ Department of History Education, Faculty of Social Science, Universitas Negeri Medan, Indonesia ${ }^{1,2}$, \\ Department of Anthropology Education, Faculty of Social Science, Universitas Negeri Medan, \\ Indonesia $^{3}$
}

\begin{abstract}
The Esplanade, also known as merdeka square of Medan City, was founded by the plantation company Deli-Maatschappij at late 19th century. Not only its function as a public open space, the esplanade is seen as a meeting point for the plantation community of Deli-East Sumatra and is a gift from the Dutch kingdom to the Deli pioneers as a symbol of the history of urban planning in the Dutch East Indies or a monument to the pioneers of the city of Medan. This study aims to write down the history of the esplanade as a symbol of colonial city civilization. This study uses a historical approach consisting of source collection, source verification, interpretation and historiography. As a printed monument of the city of Medan, the reality that was built on the esplanade was essentially interpreted to support urban civilization/urban society during the colonial period.
\end{abstract}

Keywords: Esplande, History, City Medan, Colonial.

\section{Introduction}

According to the Law on Cultural Conservation Number 10 of 2010 article 11, the Cultural Conservation Area is a geographical space unit that has provisions if: a. contains 2 (two) Cultural Conservation Sites or more which are located close together; $b$. in the form of a human-made cultural landscape that is at least 50 (fifty) years old; c. has a pattern that shows the function of space in the past aged at least 50 (fifty) years; d. showing the influence of past humans on large-scale spatial use processes; e. show evidence of the formation of the cultural landscape; and $\mathrm{f}$. have submerged layers of soil that contain evidence of human activity or fossil deposits. These criteria are owned by Merdeka Square (esplanade) so that Medan Merdeka Square (esplanade) is appropriate to be used as a Cultural Conservation Area which has 2 cultural heritage sites namely the proclamation monument and the field landscape itself which is 50 years old and over and has cultural landscapes and evidence. history in the Medan-North Sumatra city area.

As the zero point of the Medan Kilometers, Merdeka Square is an area located in the heart of Medan, North Sumatra. Based on 30 35' 26" N 980 40' 42 E, 323 m, located in the Kesawan area, Kec. Medan Baru, the city of Medan-North Sumatra which is surrounded by major roads such as City Hall Street, Bukit Barisan Street, Medan Railway Station Street and Pulau Pinang Street [1]. The current reality is that the 25-hectare esplanade public open space is only 
interpreted as a public space that is used as a place for official ceremonies for the city-regional government, a place for sports, a place for young people to date, a place to play, a place of worship, a place for art practice, and even a place for buying and selling. used books. However, when viewed from the perspective of history in the colonial period, the function of the 'esplanade' independent field had become symbols of glory in its time which was full of evidence of the civilization of a colonial city.

As a square-shaped space with full of vegetation around it, the esplanade certainly has a long history with various changes that occur in it. What was originally functioned as a park for the station (stationplein) at the end of the 19th century (see letter of agreement Grantrechten in Delï" No.12 Resident of East Sumatra in 1891) by the Deli-Maatshappij company later turned into a public open space whose management was carried out by the Deli-Maatshappij company. Medan city government, Mayor and City Council (Burgemeester en Wethouders) [2]. The Esplanade, which was initially pioneered by a private company, has become the property of the Medan city government. The meaning is that the esplanade is interpreted as an official government place that is intended for the interests of colonial powers in their colonies.

The early development of the esplanade could not be separated from European entrepreneurs in the land of Deli (Delian). They considered that the esplanade was a meeting point for the Deli plantation community in East Sumatra [2]. Not only as a city square and a central point, these Delians said the esplanade was a gift from the Dutch prince or the Dutch kingdom to the Deli pioneers (European Entrepreneurs) as a symbol of the history of urban planning in the Dutch East Indies or a monument to the pioneers of the city of Medan. Esplanade is interpreted as a pioneering monument for the city of Medan [3].

Apart from being designated as a public open space that anyone can access this space, the esplanade also functions as a city park and various activities and entertainment for the people of Medan. The function of the esplanade as a public open space signifies the characteristics of modern urban areas during the colonial period. Meanwhile, the existence of an independent field that surrounds the colonial administration office indicates that the esplanade was created for the benefit of the Dutch colonial government and also for the purpose of economic production and control [4], which at that time the city of Medan became the administrative center of East Sumatra as well as the administrative center of plantation companies operating in the area. In its development it is considered a symbol of the "Delian" cultural system (pioneer pioneering deli) and the pioneering monument of the modern city of Medan.

The esplanade has not only become a symbol of the power of the colonial government but also physical changes, and the meaning of society towards the esplanade during the colonial period. In particular, the esplanade became a symbol and urban monument of the Dutch colonial government in which all the realities of the supporting urban society were contained. All elements of society formed the esplanade into a colonial city civilization during the colonial rule of course.

\section{Results and Discussion}

\subsection{Esplanade as Railway Station Square (Stationsplein)}

The naming of the independent field during the colonial period was called esplanade which from Dutch means open field, if in cities in Java the esplanade is called alun-alun. Before becoming an open field, this esplanade was still a tobacco plantation area and full of 
brackishness [5]. The position of the explanade which is 300 meters near the DeliMaatschaappij office, an area where there are still few main buildings nearby such as the Deli Maatschappij hospital and an army post (garrison) consisting of about 100 members are the right reasons for establishing various infrastructures especially the esplanade [6]. DeliMaatschappij was the largest company in the management of Deli tobacco cultivation, which was famous in the world at the end of the 19th-20th century. This company became the forerunner of the first construction construction in the city of Medan, which was once a village under the administration of the Deli Kingdom.

The making of Medan as the center of plantation administration by the assistant resident of Deli replacing Labuhan Deli in 1879 caused Medan to develop rapidly marked by the existence of European-style building infrastructure built by European plantation companies including the esplanade. In addition to the esplanade, the previously built infrastructure, namely the train station in the European architectural style, the societeit building is a place for gatherings of Europeans built using stone and European architecture, and the post office (Staatsblad No. 205/1879 in [7].

According to Passchier "Medan; Urban Development by Planters and Entrepreneurs 1870-1940" in Peter J.M. Nas (ed.), Issues in Urban Development; Case Studies from Indonesia [7] precisely in 1880 the open land in front of the post office was turned into a square which was named the esplanade. In the 1870s the explanade was an empty tobacco field and a decade later it was transformed by Deli-Maatshappij into an open field equipped with roads and European building constructions which were realized in the following years as to the right of the esplanade there is a view of Deli Station Spoor Maatschappij, Hotel de Vink, barracks, Fort, Great China Shop, Racecourse, Resident's Mansion, and European-style whitewashed Deli Company Building [8]. Two centuries later, in 1891, through the Control Grant to the Deli Company No. 1 of 1891, this grant was the result of an agreement between the Sultan of Deli and Deli-Maatschappij who had donated about 225 ha of land. for the development of the city of Medan including land grants for the esplanade in it. The rights and obligations obtained by Deli-Maatshappij on these lands are equivalent to the current power of the Medan Municipality. Part of the grant number one is intended for the personal use of DeliMaatschappij, the rest is for public purposes such as streets and squares located within the city limits of Medan which will be built for public use (Grant No. 1 article 8 on 18 February 1891). Initially the esplanade was a rectangular area of the train station square (stationpein). According to a letter from the Resident of the East Coast of Sumatra, Mr. W. Michielsen dated March 6, 1891 number 1169/4 esplanade was used as a public open space (public), closed to vehicles and administrative functions were fully managed by Deli-Maatshappij [2]. The main function of the esplanade at the end of the 19th century was as a square-shaped field that served as a public open field that was part of the railroad square. This decade the esplanade became the bustle of every train tram stop. Passengers going up and down make the esplanade look crowded on the front side of the train. 


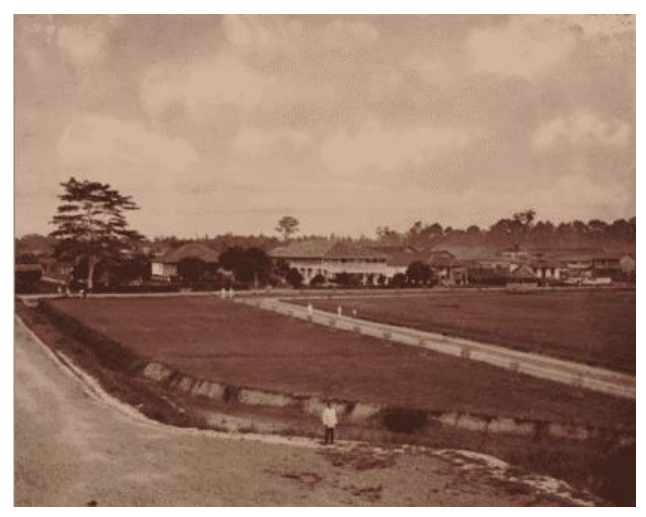

Fig. 1. Esplanade During Early Construction in 1886 [9].

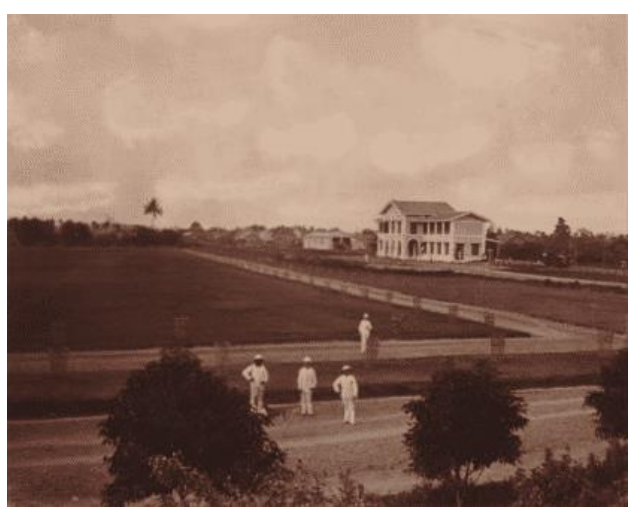

Fig. 2. Esplanade During Early Construction in $1886[10]$

At the beginning of the construction of the esplanade at the end of the 19th century, if seen from Figure 1, it can be seen that it was only an empty field planted with trambesi trees (Samanea Saman). The planting of a trambesi tree by the Deli Maatschapij company to add to the green city layout in the tropics and this tropical plant species functions as greenery, absorbs dirty air and provides shade and is a large, tall, and long-lived tree. Special trambesi trees were imported by the Dutch colonial government from tropical America such as Mexico, Peru and Brazil at the end of the 19th century [11]. In addition to the trambesi tree in the next decade, the colonial government planted a Wilhelminia tree (Wilhelminahboom) or known as the banyan tree. This plant was planted in one of the esplanade areas in 1898 with the consent of Queen Wilhemina to mark her wedding celebration [12].

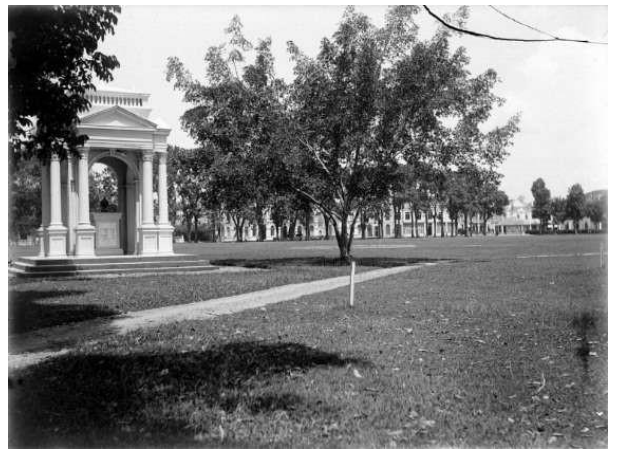

Fig. 3. Tamiang Monument at the Esplanade in Medan 1900-1922 [13].

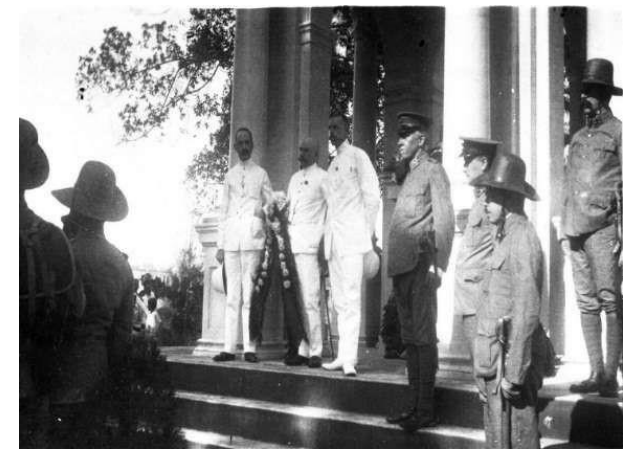

Fig. 4. Wreath laying ceremony at Tugu Tamiang On April 30, 1918 in Medan [14].

When viewed from various sources from the old photos above, it can be seen that the construction of the esplanade carried out by the Deli Maatschappij company was simply a square field equipped with hundreds of tree seedlings, asphalt paths, ditches surrounding the esplanade, bridges, stone pole fences and monuments. There is no grand design yet, only an empty field to complement the train station, accompanied by several other developments. The development of this green open space has also not been able to overcome the flooding in the 
city of Medan at the end of the 19th century. In 1893 the esplanade was flooded as can be seen from the picture below:

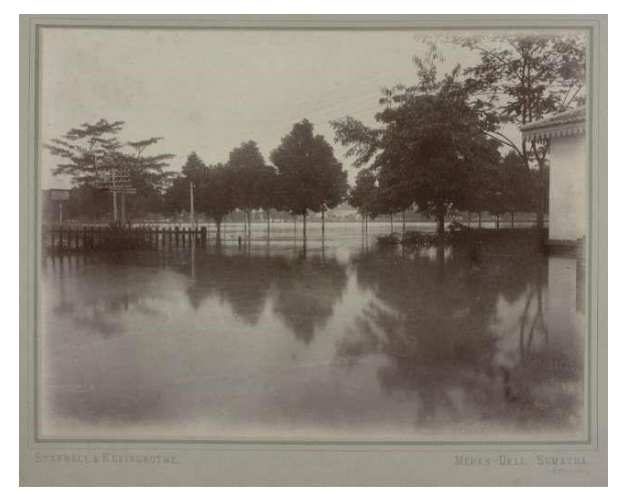

Fig. 5. The Flooded Esplanade of 1893 [15].

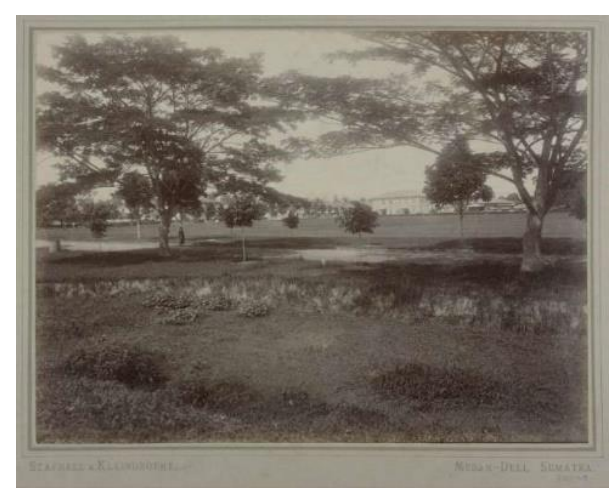

Fig. 6. The Flooded Esplanade of 1893 [16].

\subsection{Esplanade as a Public Open Space and Symbol of Colonial Power}

Along with the success of the Deli plantation industry at the end of the 19th century, Medan became the administrative center of Deli plantations as well as the center of the government of East Sumatra, Medan became the capital city for the East Sumatra region (Oostkus Sumatra), the most important plantation area in the outer islands [17]. The progress of the Deli plantation industry with the presence of European companies in the city of Medan had an impact on the development of office buildings in the city of Medan and Medan automatically became the ensclave of gardeners (European entrepreneurs). Medan became a destination for Europeans to develop their economic business ventures. The presence of more and more Europeans was one of the factors driving the Dutch East Indies government to establish Medan as a gemeente in 1909 [7]. As a result of these advances, Medan turned into a city that underwent a process of rapid modernization and became a Metropolitan city on the East Coast of Sumatra. European architectural buildings, such as Witte Societeit, Post Office, Gemeentehuis (Kotapradja Building, Hotel de Boer and Hoel Medan, Horrison \& Crossfield Company Office, Deli-Maatschappij, Deli Proefstation, Deli Spoorweg Maatschappij, Firma van Nie en Co., are a building that symbolizes the modernity of the city of Medan [7]. All of these modern buildings surround the esplande as the center of modernization of the colonial city. The esplanade becomes the embryo and center of the development of the city center of Medan [18].

The modernization of the city of Medan was recorded in Augusta De Wit's colonial report on nature and people in the Dutch East Indies. with expensive new goods, having clean and clear waterways in every corner of the city, in residential areas the houses have electric lights, lawns and flower beds. Even in small Chinese and Indian-British settlements having an air and light environment characterizes prosperity. Everything looks well-groomed, meticulously organized, and well-groomed [19]. This report also tells about the esplanade, which is a park and square surrounded by large and tall buildings, when in the morning the atmosphere of the explanade is cool, there are crowds of football and tennis players playing at the location of the explanade. On the esplanade you can see people of all nationalities, including Chinese traders, Bombays, Japanese, Bengalis, Sikhs and Arabs [19]. The image of a colonial city and 
modernization has become part of the colonial city of Medan in the second decade of the 20th century as evidenced by various European travel reports and colonial records describing it. In addition, the characteristics of colonial cities such as segregation of settlements based on ethnic races, both Chinese-Indian, Arab, Indigenous and European settlements are also shown in the note. The city of Medan is a metropolitan city created by the colonial that resembles other European cities such as Batavia and Surabaya.

Meanwhile, on April 12, 1921, there was an exchange of land between the municipality of Medan and Deli-Maatschappij, where the land given by the Sultan of Deli to Deli-Maatshappij in 1891 about 150 ha including the esplande area was given to the Municipality of Medan as a sub-grant of Deli-Maatshappij, a sub-grant this became the basis for the development of the esplanade area. In 1921 the management of the Esplande was transferred to the Municipality of Medan with an agreement that the esplande will continue to function as a public open field and become the meeting point of Medan [2]).

The esplanade sub-grant in 1921 carried out between Deli-Maatshappij and the Municipality indicated a change in the ownership function, namely Medan Municipality and the function of the railway square to become a public open square. The function of the esplanade is as a public space, where it is a public open space for anyone in the colonial city in the Medan area. The Esplanade was built in the form of a rectangular city park, each side surrounded and planted by trambesi trees by the colonial government. This trambesi tree is intended for reforestation, and has a strong ability to absorb groundwater. Parks and open spaces are urban concepts that develop in a more pragmatic modern life [4]. The existence of open space and space in the middle of the city are typologies of colonial cities. Coupled with the white buildings around the explanade was built really for the benefit of the Dutch colonial government.

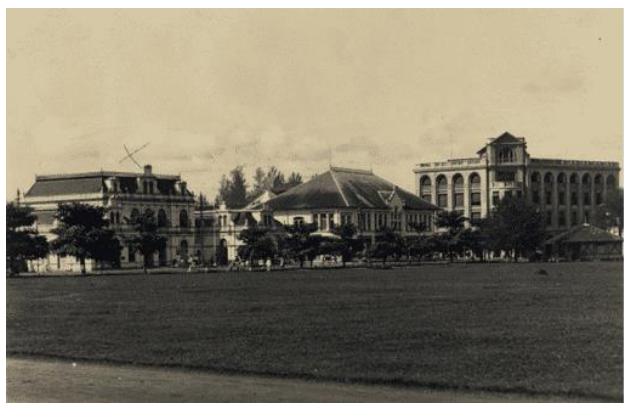

Fig. 7. Esplanade surrounded by Colonial Style White Houses 1925 [20].

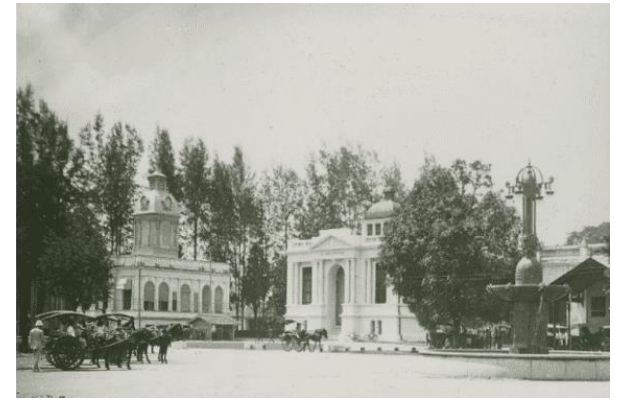

Fig. 8. The Beauty of White Buildings \& Horse Carts Around Medan City Esplanade in 1935 [21].

The Esplanade is the central center surrounded by typical European buildings and buildings. Medan is also used as a busy city, developing and becoming a miniature European city called Paris Van Sumatra. Medan as a miniature of this beautiful European city was described by a European traveler in the 1930s named Setevens who was traveling from Belawan to Medan. On his way to Medan he described Medan as a civilized place, he was amazed to see the beauty of white buildings such as the Hotel de Boer, Soos Building and a complex of buildings with several cars in front of him when he turned the road around the esplanade. Besides that, he also described the increasing traffic in both directions as cars, trucks and motorbikes were crowded and passing on the esplanade while several two-wheeled 
vehicles mounted on horse saddles attracted his attention when crossing the area around the esplanade [22]. A traveler H.Veersema in 1936 also described the condition of the esplanade which he said was the widest square in Medan. When visiting the esplanade, the European traveler was disappointed to see the condition of the esplanade which is the central point for non-Europeans (foreigners or natives) unlike the square on the island of Java which is much more beautiful and far from non-European people [23]. It means that he imagines the concept of the esplanade in the city of Medan as a public open space for anyone who comes, including non-European people at that time. This is different from the concept of most squares in Java such as the Bunder Square in Malang City which is consistently positioned as a closed area, both physically and symbolically [4].

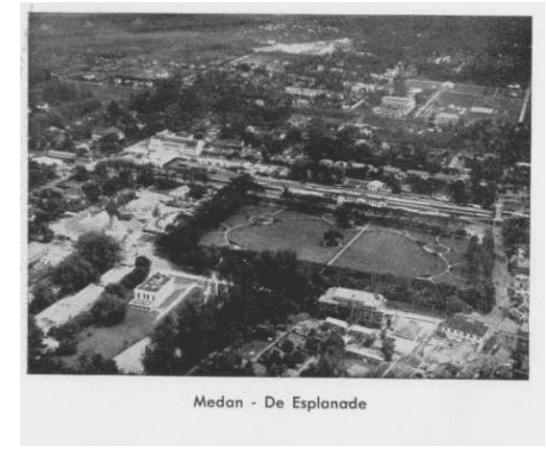

Fig. 9. Medan-Esplanade [24].

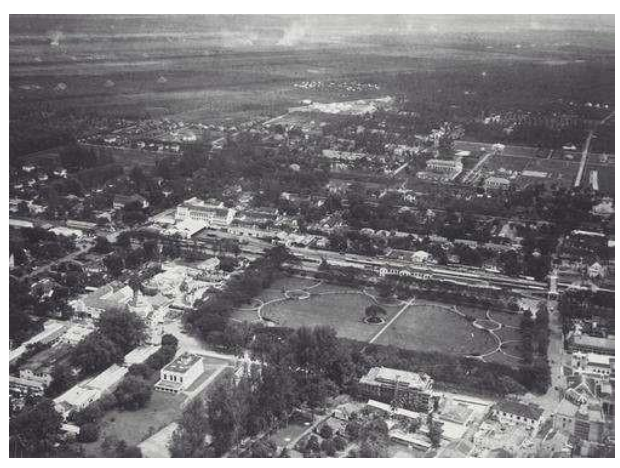

Fig. 10. Aerial View of Medan Including Esplanade, Tropical Region 1931 [25].

The control of the esplanade by the Medan municipal government in 1921 indicated that this public space became a symbol of the colonial government's power over the city of Medan. Esplanade is intended as a city park whose development is not separated from the development of the city of Medan. In this era, the colonial government tried to make big projects with ideas or images that required a civilization of the European-colonial nation. The development images that will be created are the establishment of a fort at the entrance to the esplanade, which resembles the entrance to the old Dutch old market square and various programs of ancient Dutch entertainment activities will appear on the esplanade. The construction of the fort is planned to be built in September 1938 which was designed by the famous Dutch architect Han Groenewegen. The construction of this fort was established to welcome the Dutch Government Jubilee Festival in September. A sketch of the entrance gate located opposite the White Society building (BCA Office). The basic material of the walls of the esplanade gate is made of Dutch bricks, the roof and windows are painted in fresh blue and red. The gate depicted in the courtyard of the esplanade will be built with a moat with solid contours and built to span two old Dutch bridges. As you walk across one of the bridges you will see a wide esplanade, with an old Dutch-style faade on all sides. The architecture of the esplanade is modern in style and has the concept of an ancient romantic image resembling an old Dutch city landscape. A luminous fountain will be placed in the center of the esplanade and of course resembles the old Dutch style as well. If someone crosses the esplanade look at the side of the esplanade of a theater building and face the entrance of the esplanade. The theater stage was built wide and magnificent which was specifically designed according to the technical needs of the drama. The theatrical program will be filled with drama with the famous play 'Kloris en Roosje' with a performance directed by Ms Boer-Kingma. The show is also 
filled with dance parties and songs that are colorful and match the old-colonial Dutch atmosphere. The planned development projects are certainly not only for the millions of indigenous peoples and the prosperity of the people under the orange flag (colonies) but for a symbol of respect for the princes and the Dutch empire [26].

In addition, the planned development project on the esplanade will have a restaurant built on both sides of the theater and one can enjoy a very good overview of the whole restaurant terrace. The restaurant will be rented out to companies or individuals who then the restaurant tenants can arrange entertainment exhibitions or sales according to the tastes of the Medan community. Therefore, in the first half of September, the center of Medan on the esplanade will present a very unusual but very interesting spectacle, which will not only attract Delian people (Deli plantation communities), but also many people outside the borders of residence in the motherland. the city of Sumatra will be present at this event. However, the design and design idea could not be implemented because the Medan city government did not have sufficient finances to build a project of this magnitude [26]. The Esplanade became a place where the colonial government imagined (imagi) a colonial city civilization that resembled an ancient Dutch city.

The biggest desire of the Medan city government is not only to build an ancient Dutchstyle fort and the facilities in it, but the city government is also planning to build a mega project for the Medan New City Hall (Gemeentehuis) office. According to a newspaper report in 1939, the Medan City Council (Gementeraad) had decided to build a new town hall on the esplanade. Meanwhile, the old town hall will be sold to Koninklijke Paketvaart Maatschappij (KPM), a Dutch private shipping company. The new town hall building will be erected right on the esplanade with Mr. architecture. Groenewegen van Valk in collaboration with the chief director of municipal works (gemeentewerken) Medan [27]. It is planned that the new town hall will be built with an area of $60 \times 70$ meters, the building space with both sides of the new town hall is about $85 \mathrm{~m} 2$. Meanwhile, in front of the new town hall, precisely in front of Jalan Cremer (Cremerweg), a square field of $115 \mathrm{~m} 2$ will be built. If we imagine that the new town hall will be an architecturally beautiful and monumental building, where all the services of the city are housed. Medan became a beautiful city center because of the architecture of this city hall [28].

However, the city hall has not yet reached the stage of construction, the community has sued and rejected it, especially the Delians (European gardening entrepreneurs). Various reports in local newspapers such as Deli Courant, De Sumatra Post, and Algemeen Handelsblad van Woensdag reported on the rejection of the establishment of a new town hall on the esplanade. According to reports, this building not only destroys the existence of the esplanade as a beautiful and green open field, but also from historical considerations in the context of the pioneering history of the development of the Deli community, which considers the esplanade as a pioneer monument of the city of Medan. The pioneers of the development of Deli said that "the esplanade was a gift from the Dutch prince or the Dutch kingdom to the pioneers of Deli (Delian) who became a symbol of the history of urban planning in the Dutch East Indies, not only serving as a town square. Historically, the esplanade is a place where the traditional ceremonies of the sultans or tribal chiefs are held. The Medansche Esplanade (so named because of the influence of its location on the strait) was a common project in the cities of the Indies, whose dimensions are difficult to identify as a symbol of the spiritual space of the Deli pioneers. We must preserve the esplanade as a relic of the previous generation and more important than for the current generation. But note that the beauty of the esplanade is better and second to none if it is not marred by the construction of the City Hall. Esplanade is the most beautiful square in the cities of the Indies although the beauty is disturbed by the side 
of the train station. If the city hall was built, the esplanade would not be touched by the public, especially the people walking on the stationsweg and if this strange development occurred on the esplanade, the esplanade would die like many alun-alun in Java [28].

One of the De Sumatra Post reporters who rejected the construction of the new city hall had submitted a request to the Medan city government, namely 1) the construction of the new city hall should be in the location where the old town hall is now standing, 2) or in a place other than the esplanade, for example across the building. Haandels Vereeniging Amsterdam (HVA) in Sultansweg The first proposed application was rejected because it was impossible on the grounds that the municipality had no money to borrow to demolish and rebuild new construction other than selling the old town hall to obtain the necessary financial resources. In addition, this application is also impossible because the new modern city hall building requires a large space and the land around the old town hall is not available. The last request, namely the construction of a new town hall outside the esplanade in Sultanweg, was also rejected on the grounds that the Sultanweg area was not considered a suitable place for a new town hall. The town hall should be located in the heart, in the center of the city and not more or less behind the ring road where the land will be used for housing [28].

This refusal of course also has a basis, namely the decree "Grantrechten in Deli" No. 12 Resident of East Sumatra in 1891 written by Gerard Jansen, former Head of the Land Office of Medan City, it appears that the esplanade is designated as a public open place in Medan. This agreement letter certainly contradicted the grand plan of the Mayor of the Municipality and Councilors (Burgemeester en Wethouders) to build a new town hall on the esplanade [29]. Finally, this refusal was considered with the support of architectural-engineer debaters and prominent Deli (Delian) figures in the city of Medan. These considerations and opinions were reported in the daily De Sumatra post with the title "Opinions on the Construction of City Halls on the Esplanade, Objections Due to the Disadvantage of Urban Aspects, etc." on August 4, 1939. As for the various opinions of architects-engineers and Delian about the construction of a new town hall on the esplanade namely:

Mr. P. Koreman. An engineer and architect in Medan who is a member of the evaluation committee for the construction of the new town hall. This lord gave the opinion to the city government that a developing city should have a square or open field and it was sad if there was development on the esplanade square. For him, the esplanade provides an incredibly beautiful view when we come to the city of Medan like a forest in the middle of the city, but it would be nice if the vegetation or plants on the esplanade field were given a better appearance. According to him building a new town hall on the esplanade means destroying the urban aspect and any development on the esplanade can only lead to disappointment.

Architect Mr. Van der Ven. An engineer who has built the gouverneurshuis (governor's house) and knows a lot about the history of the esplanade said that the preservation of this most beautiful town square of the esplanade is far more important than any building, in other words the construction of a new town hall on the esplanade is a customer The largest and most beautiful square in Medan-East Sumatra. Moreover, the construction of the new town hall was completely against the traditions and agreements previously made for the esplanade.

The ancient Delian leaders. Who are represented by Tuan De Boer (owner of the de Boer hotel), Tuan vd Ven (European Entrepreneur) and De Factorij (European Company) who had designed from the beginning the esplanade square as a meeting point for the city center of Medan-all Deli should maintained function. According to them, the esplanade must be 
preserved as an open space and garden that is free, spacious, valuable and if construction is carried out it will eliminate the character of the public open square. Not only the ancient Delians (Deli entrepreneurs) like Mr. De Boer who thought this way about the open field of the esplanade, other white people also agreed with these ancient Delians that the esplanade should still be used as an open field and as a meeting point for Delis that did not touched by its existence.The party suggested the construction of the city hall should be in the city center where Europeans, Chinese and Indigenous people can reach the city hall with a close distance such as two major crossing arteries namely 1) Boolweg-Cremerweg-Kesawan Paleisweg with Sulthan Maarnoen Alrasjidweg-Smitsstraat or the Paleisweg intersection -Smidsstraat and Sulthaan Maarnoen Alrasjidweg and nearby is an open area opposite Handels Vereeniging Amsterdam (HVA). This location is much better for the town hall than destroying the esplanade as a testament to Delians culture.

Ir. J. O de Kat. An engineer who built Medan's first water company, argued that the construction of the new town hall was the same mistake that the Medan city government had made in the past, as was the case with the Kongingsplein esplanade in Batavia, which damaged one side of the esplanade by building telephone offices and hotels. SS on the Koningplein esplanade. A city needs a big field and the people of Medan are lucky enough to have an esplanade compared to other cities. The community views the esplanade as a place of "adatplaats" which is very important for the community. The development that will occur will violate the traditions and beauty of the esplanade. In the opinion of Mr. Ir. JO de Kat, he does not want to talk about opposition or support for the new town hall construction project. , because this is an internal matter for the Medan city government but he believes that the esplanade should be left untouched by any buildings.

Ir. Niels Thiele. A Medansche concrete engineer, expressed his opinion that he lacks confidence in the Medan Municipality's successful plan to build a Baru town hall on the esplanade. According to him the esplanade will be extended by various wooden constructions and the entire side of the esplanade will be turned into a city hall garden but he questioned "can we save the esplanade by building a dignified town hall?" According to Mr. Niels Thiele, "this is not completely impossible, but it will definitely cost more of two hundred thousand guilders. For such an amount the government will never be able to erect the building on the esplanade and be responsible for the existence of the esplanade.

Mr. Van den Heuvel. A representative of the Langereis company, who has also observed the development of the city of Medan for many years, believes that the development on the esplanade is not on target or misses the previous plan. It is believed that building a new town hall on the esplanade will not make the town hall the center of all city services. I certainly don't want to bring city cleaning, municipal works, construction companies and the like on the Esplanade? Mr. V.d. Heuvel suggested looking elsewhere in the city to build a new town hall, for example in an area near a river such as Kebon Boenga (flower garden in front of the governor's official residence) which is on the main road and close to the river allowing the city cleaning service to be located. In general, Mr. v. d. Heuvel said the municipality's goal to build a town hall on the esplanade was regrettable. From an urban planning point of view, this is very much to blame. According to him, this planning started from the consideration of the municipal government's financial savings because the esplanade is land owned by the municipal government which does not require land purchase costs, thus saving the budget. 
Mr. Hartog. An architectural bureau Meeuwse and Hartog said it would be a shame for the esplanade if the Mayor's Council (Burgemeester en Wethouders) plan would continue to build a new town hall on the esplanade. It would be much better to tear down the old town hall and build a new building there. Although one hundred and fifty thousand guilders will be lost to demolish the old building, what should not be ignored is the huge cost of building an area of land on an esplanade of 25 hectares. From the urban aspect, the city of Medan must have a beautiful alun-alun and if there is a lot of construction going on in the central area of the meeting, of course it will change the area and it is certain that all proportions of this alun-alun will be totally destroyed.

Mr. Schipper of the Bureau of Architecture and Tile Factory Bennink and Co. He used to design Ned's new building. Indische Handelsbank does not agree with the previous opinion or supports the construction of the Medan city hall. According to him, the construction of the new city hall is very suitable to be built on the esplanade. That the city hall must have a good environment and the esplanade is the only place that is suitable, appropriate and in accordance with the project of the mayor and the city council. Mr Schipper believes that the construction of a new town hall will not accelerate the destruction of aspects of the city, whereupon he adds that this is an appropriate way to halve the total area of the city center for town hall purposes, it is not a heavy and serious matter to delay the construction of a town hall on the esplanade.

The debate between the city government and the people represented by various community leaders in Medan, the Delians, engineers, other Europeans and the press, continued until the end of 1939, as can be seen from various mass media such as Het Nieuws Van Den Dag Vook Ned.Ïndië on 26 August 1939 [30] under the title War for the New Town Hall (From our Medanschen correspondent) Medansche Town Hall Sale and 28 December 1939 [31] under the title Esplanade. Based on this news, the construction of the new Medan City Hall on the esplanade was due to the large profits of the municipal government from the sale of the old town hall by the Dutch shipping company K.P.M who brought one ton of money to the Medan city government. This advantage makes the government plan to build a new town hall on the esplanade, which is free of charge and can save the budget compared to buying new land outside the esplanade. This news shows that there is a political interest of the city government for the construction of a new city hall which actually ignores the spatial aspects of the city and the interests of the people of Medan. In essence, many architecture, Deli (Delian) leaders and the community opposed the construction of a new town hall on the esplanade, this rejection of course based on aspects of urban planning and the community's need for public open spaces. In general, these development plans were shown to serve the interests and colonial power.

The Esplanade is not only a symbol of the "center" of the Medan city government's power, but also the node of the entire series of city government activities and initiates the development of a Medan city. The Esplanade was actually used by the city government as a public space that had many functions to stimulate the activities of the Medan city government in its colonies. The Esplanade is used as a place for official and non-official activities which signify the urban concept that is developing in modern and pragmatic life built by the Medan city government.

Various official and non-official activities such as lifestyle and entertainment were carried out on the esplanade to support the activities of the colonial government. Various big celebrations were carried out by the colonial government on the esplanade, such as in 1904 a celebration was held in honor of the birthday of H.M. Queen Wilhelm. H.M.'s birthday 
celebration Queen Wilhelmina was celebrated almost every year by the colonial government. This celebration was very important for the colonial government as evidenced by every August 31, Wilhelmina's birthday was celebrated in the Dutch colonies, especially in the city of Medan. As the ruler of the Netherlands, Queen Wilhemina not only has economic and political power in her colonized country but also culturally [32]. This cultural power is expressed through various activities and events in celebration of Queen Wilhemina's birthday. As happened on August 13-31 August 1904, on the esplanade, Queen Wilhelmina's birthday was celebrated. This celebration held a flower parade which began on August 30, 1904 at five in the afternoon until in the evening there would be lighting in the yard of every house in Medan. Then the next day, on August 31, 1904, at three to six in the afternoon there will be a folk game on the esplanade, then at half past eight in the evening there will be dinner, where 140 people will come to dinner and everyone is free to come with whatever costume they want. they want (black suit or plantation costume). Then at ten at night there would be music and at eleven at night there would be fireworks on the esplanade. The celebration was carried out by various committees and donations from field entrepreneurs such as donations for illuminations and fireworks from Mr Kuhr and Captain-China, flower parade from Mr Kuhr and Van Vollenhove parties from Capt Military Camp, folk games from businessmen Dinter and Weyhenke, dinner from Mr van Dinter, Kruger and Weyhenke [33]. This birthday celebration also occurred in 1908 when the colonial government made a gate with wooden construction on the esplanade, and various exhibitions in the Merdeka Square.

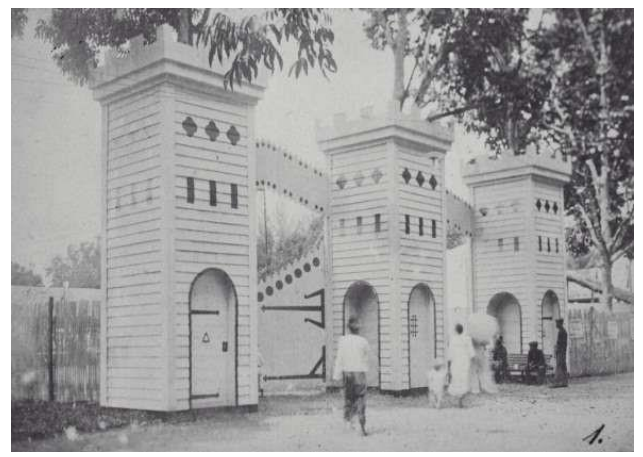

Fig. 11. Esplanade Main Entrance During Exhibition in Medan, 1908 [34].

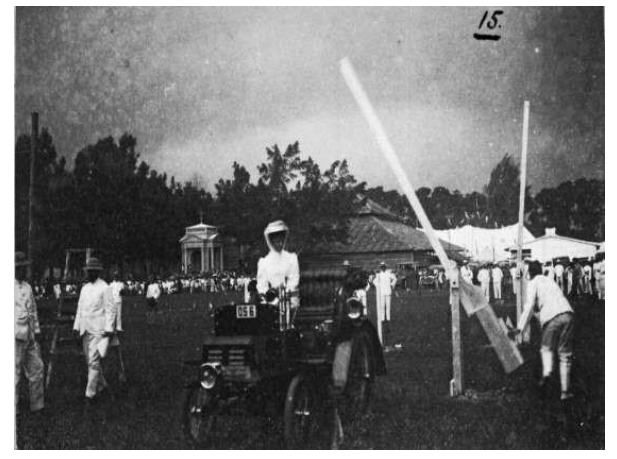

Fig. 12. A European Woman Driving a Car Past Duty During an Exhibition at the Esplanade, 1908 [35].

The colonial government held various events involving government officials, businessmen, and the people of Medan. The celebration was carried out to express joy, gratitude, and pay respects to Queen Wilhemina who was in the Netherlands. Even though the Queen and her family are quite far away, the energy of her power must still be used as a "life mover" in the colony. More than that, broad community involvement can be read as an effort to present royal and colonial power in cultural life, without having to cause fear [32]. Like the celebration that was covered by the Deli Courat mass media on August 17, 1939 with the title "Queen's Day, Celebration Program". On the occasion of the birthday of H.M. Queen Wilhelmina who will come on August 31, the Orange Committee will hold several celebrations in the city of Medan, of course the center of its activities on the esplanade. This event includes:

1. At 06.30 a.m in the morning a flag ceremony was held in the residential courtyard. 
2. At 07.00 a.m ring the church bell.

3. At 07.45 a.m a military parade and wreath laying at the Tamiang esplanade monument with a parade on the route Kazerne - Demmeniweg - Cremerweg Societeitsweg Stationsweg (Tamiang Monument) - Nienhuysweg - Kesawan - Soekamoelia Residenthuis - Poloniaweg - Kazerne.

4. At 16:30-18:00 p.m a football match (final round) will be held

5. At 18.00p.m military concert on the esplanade with free admission

6. At 6:30 p.m Boy Scouts bonfire on the esplanade.

Various celebrations were held by the colonial government by displaying various official government events, religion, sports and music concerts on the esplanade. Like Queen Wilhemina's birthday celebration which is carried out almost every year by displaying big activities and consuming a lot of money, of course. Such as making a magnificent gate with the form of ancient Dutch forts made of wood and a large parade to welcome Queen Wilhemina's birthday. The construction of this fort is of course very expensive and certainly represents a symbol of Dutch civilization (see picture .11). The colonial government brought a European atmosphere to every celebration event made by the Dutch colonial government. This event is certainly a representation of the lifestyle of Europeans and people outside Europe only as workers and as spectators of the event. The celebration conveyed that what happened in the colony was in the name of the queen of the Netherlands' power or the image of the colonial government.

In addition to the birthday celebration of H.M. Koningan Queen Wilheminna there was also a celebration of Michiel de Ruyter on the esplanade on 24-03-1907 and in 1913 a hero admiral who was the most trained in Dutch history whose job was to fight against England and France in the 17th century. De Ruyter won many naval battles and eventually died in action against the French at Syracuse on 29 April 1676 [36]. The festival holds a maritime-themed parade such as an ocean liner depicting the Dutch ships ridden by Admiral Michiel de Ruyter in the 17 th century and various maritime-themed train parades. The festival is carried out by the people of Medan, especially the Europeans. It can be seen below the photo of some European children on the boat parade and local people making the boat parade. All people can see and witness the parade activities.

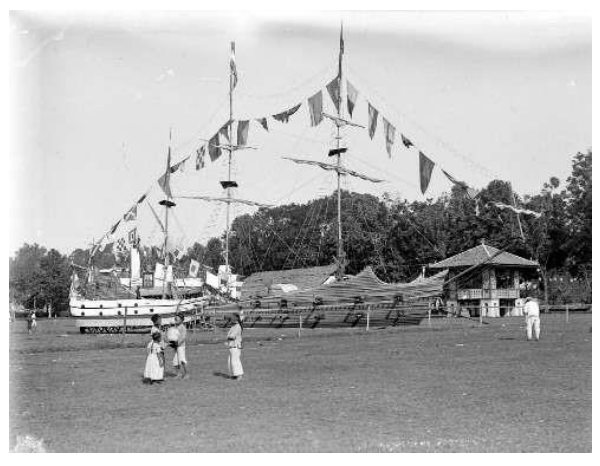

Fig. 13. Michiel de Ruyter's Celebration at the Esplanade, 24-03-1907 [37].

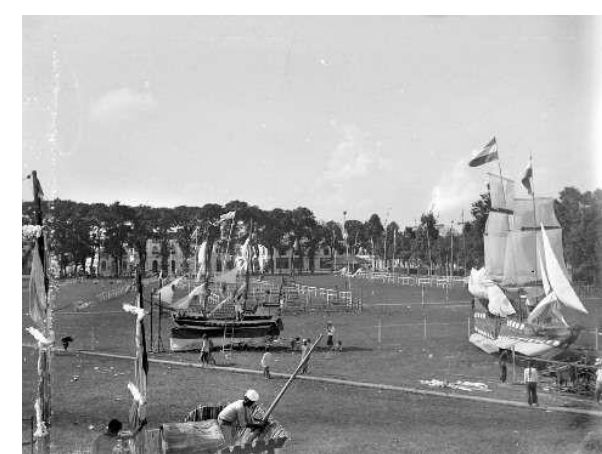

Fig. 14. Michiel de Ruyter's Celebration at the Esplanade, 24-03-1907 [38]. 


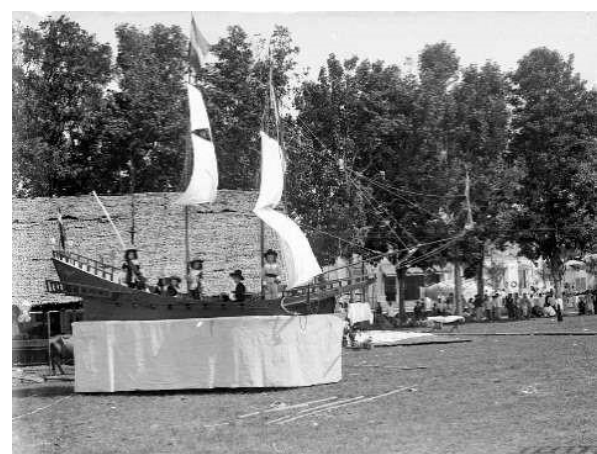

Fig. 15. Michiel de Ruyter's Celebration at the Esplanade, 24-03-1907 [39].

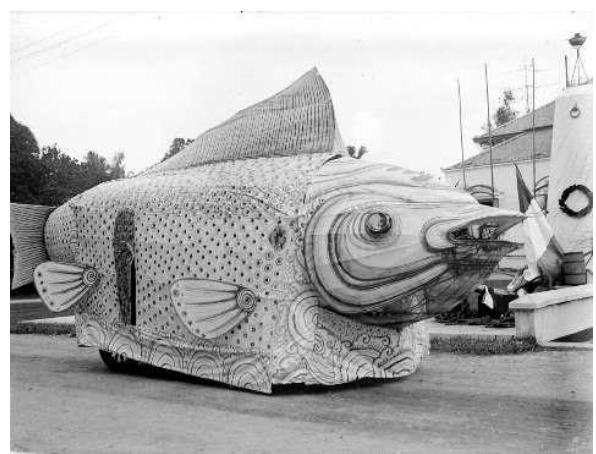

Fig. 16. Fish Float During Michiel de Ruyter Celebration at Esplanade, 24-031907 [40].

The celebration of the independence of the Netherlands is also commemorated on the esplanade, it can be seen from the photo of the independence celebration below with the float procession that took place in 1912-1920. This celebration held various Dutch-themed train parades such as a decorative ship with the Dutch flag, a decorative carriage with people dressed in Dutch royal clothing, an ornamental oxcart carrying the Dutch colony, and horses carrying Dutch soldiers who were blowing trumpets and the coat of arms of the Netherlands and the Netherlands. a car carrying a lord-man europe with a statue of the king of the Netherlands. This celebration was of course carried out by the colonial government especially for the European community while the non-European people only watched the parade. This celebration can be seen below:

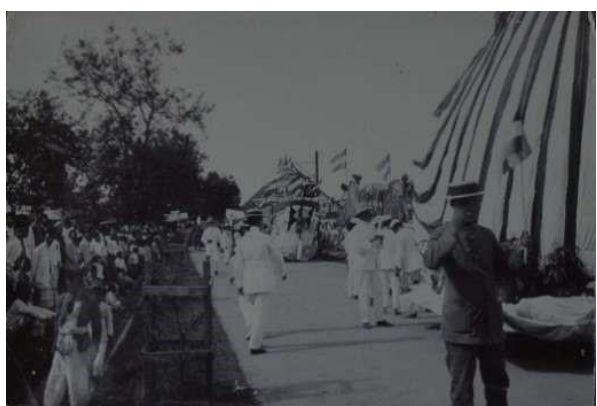

Fig. 17. Independence Celebration with float procession, 1912-1920 [41].

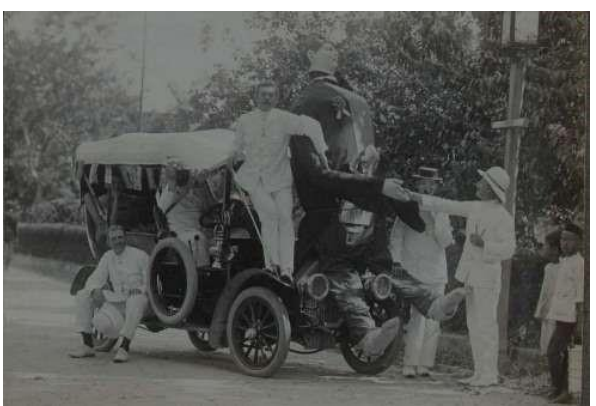

Fig. 18. Independence Celebration with float procession, 1912-1920 [42].

Official activities on the esplanade were also carried out by the Dutch colonial government, such as paying homage to the pilot and engineer of the first Dutch-Batavian commercial flight during a stopover in Medan on 21-11-1924. This event consisted of pilots and flight technicians between the Governor, members of the city council, the Sultan of Deli and officials listening to the welcoming speech of the mayor of Medan, and the handing over of necklaces and gifts by a woman in traditional clothing, which was watched by the people of the city of Medan (European, Native and others). 


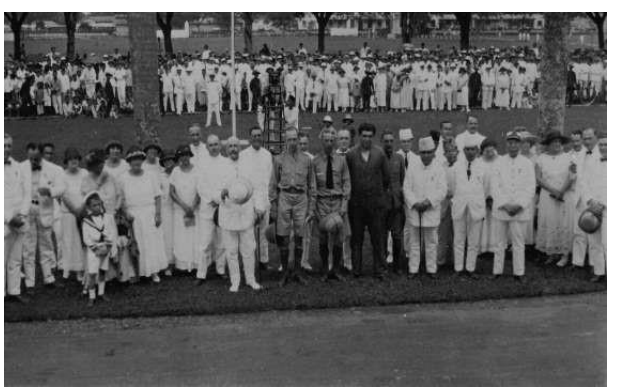

Fig. 19. Pilot and flight technician between the Governor, city council members, sultan Deli and officials listening to the mayor's speech upon arrival in Medan, 21-11-1924

[43].

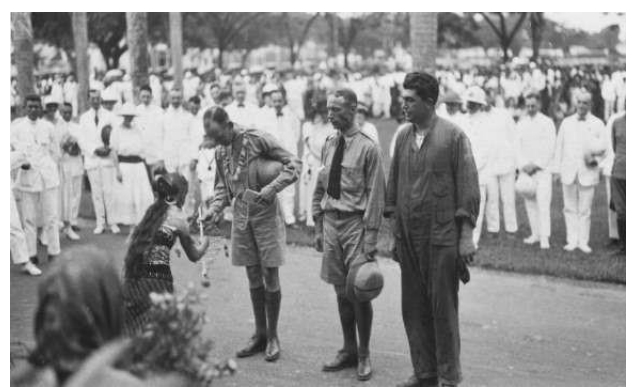

Fig. 20. Tribute to the pilot and engineer of the first Dutch-Batavian commercial flight in Medan, 21-11-1924 [44].

The Esplanade became very meaningful for the European community and for the colonial government in Medan, especially for organizing official-non-official government events and major celebrations of the Dutch government, which aimed to strengthen the image of the Medan city government. In addition to official events, colonial images are also shown in sporting activities at the explanade. Esplande serves as a field for sports games, especially football and tennis. Sports activities and representations of European lifestyles during the colonial period at the explanade are depicted in newspapers and old colonial photographs, such as the De Sumatra Post report that on August 30, 1905, a football match was held on the esplanade with the Medan Sports Club and Medansche Toengkoe-club teams. Furthermore, on Sunday September 1905 at 4 o'clock in the afternoon a match was held between the team from the club "Taoan Sefakat" Bindjey and "Club Letterzetters" Medan on the esplanade [45].Then the De Sumatra Post report on August 18, 1922 reported that a football match was held for the indigenous associations (Inlandsche) on the Esplanade. This event was held to celebrate the jubilee of the colonial government. Everyone was busy preparing the pitch for the match like the goalposts had been replaced and people were busy mowing the grass on all sides of the pitch. A hockey field has also been prepared in the esplanade area. This match will be between the Zetters against Chauffeurs Voetbalclub from Tebing Tinggi and tomorrow afternoon the M.S.V. against Medan Tapanouli [46]. On January 24, 1924, it was reported that a number of sports clubs, namely Medan Tapanoeli Sport, Zetters Voetbalclub, Batak Sport Vereeniging, Medan Sport Vereeniging, and Chinese Sporting Club had sent a letter to the mayor of Medan to lend them an esplanade in the short term. Then a football match was also held between Medan Sport Vereeniging (M.S.V) and Deli Sport Vereeniging (D.S.V) on February 3, 1924 on the esplanade. The intention was originally carried out at Bentengweg (Benteng field) but was canceled and moved to the esplanade. The composition of the team from D. S. V includes Angenent Sr, Schnifer Tomcat, Lansdorp Kabel Gobel, Brandt Patti Blommendaal Themmen Beerling, Ibrahim Pardi Gading Mansur Dahlaan, Paimin Moh. Arif Oesin, and Imang Kamarudin Said [47].

The photo archives collectienederland.nl, and kitlv.nl also show photos of football matches in 1925 and 1927. The picture shows two soccer teams in uniform taking pictures on the esplanade with the goal and crowd in the background and another photo that looks like a soccer match is taking place the ball and the spectators are enjoying a soccer match on the esplanade. The Esplande as an arena for football games is also illustrated in colonial reports 
which describe crowds of football and tennis players playing at the location of the explanade [19] (Augusta De Wit, 1914: 250) and the record of a traveler who was sent to oversee the course of football on the esplanade in 1936 [23].

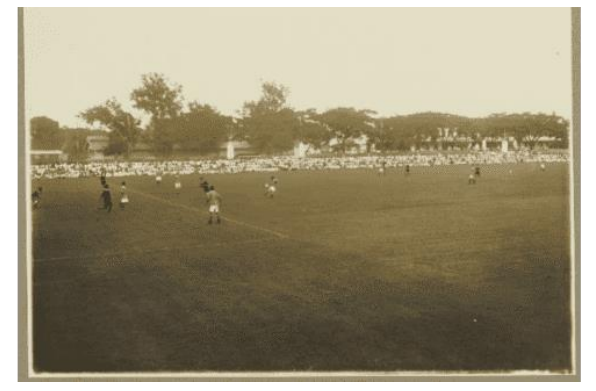

Fig. 21. Football Match at the Esplanade of Medan City in 1925 [48].

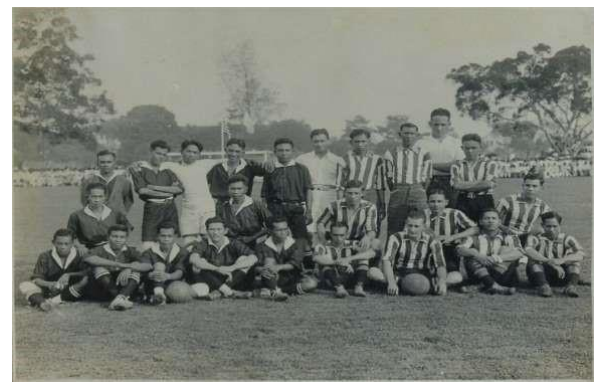

Fig. 22. Photo with two soccer teams On 0707-1927 [49].

The historical development of football in the city of Medan is inseparable from the role of the Dutch colonial government in the 20th century. The emergence of football clubs formed by Europeans indicates that this sport is part of the lifestyle of the Europeans. Football at this time displays displays of racial discrimination carried out by the colonial government. It was seen that several Chinese, Aran and Indians who were categorized as foreign easterners (vreemde osterlingen) and indigenous people founded soccer clubs based on their ethnic groups. Such as Medan Tapanoeli Sport, Zetters Voetbalclub, Batak Sport Vereeniging, Medan Sport Vereeniging, and Chinese Sporting Club [50]. These football clubs usually competed at rei and or official events held by the colonial government and private companies in Medan-East Sumatra. One of the football performances that is often held is the birthday celebration of Queen Wilhemina in the city of Medan. In addition to football, a sporting event that is often held on the esplanade is the game of hokey. On August 16, 1910 the Deli Courant newspaper reported that there was a Hokey club game every Monday and Thursday afternoon at 17.00 on the esplanade [51].

Among the lifestyles that were often displayed by European nations during the colonial era, namely entertainment with musical concert performances were often performed on the esplanade. Like the concert event that took place on November 13, 1910 with the title "Progamma, Voor Het Esplanade Concert". Before the concert there was a music event by the Niewuw-Muzeiek Corps group. This music event will feature the programs Les Patriotes Beiges by Marscli H. Reuland, Ouverture Die Italiener in Algier" by von Rossini, Les Patineurs, by Walzer . E. Waldteufel, Take Me Too. By Polka Marsch P. Lincke, The Dollar Princess Selection Leo Fall By Pauzh, Faust Fantaisie by J. Kessels, Your eyes have told me so. Song E. Carr. Hardy, Marchen Walzer by Josef Bayer and Santa Lucia Marsch By A. Lotter [52]. Then on December 14, 1910, the concert was postponed on Sunday to Monday night, December 19, 1910 on the esplanade [53]. To celebrate the birthday of prince Z.K.H. Bernhard (Husband of daughter Juliana) who was born on June 29, 1911 the colonial government organized various activities including a military parade that took place at seven to eight past a quarter of the morning in front of the residence of the Governor of Sumatra in Sulthan Maarnoen Alrasjidweg, and in the afternoon at five a music concert was held military on the esplanade [54]. Music concert events at the beginning of the 20th century at the Medan 
city esplanade were more focused on classical (westernized) music and music concerts with a military theme. Music concert entertainment held on the esplande is more precisely for DutchEuropeans and people with status like Europeans, not for the general public. Entertainment on the esplanade became the politics of colonial culture, colonial imagery and supported the activities of the colonial government.

Various official events, lifestyle and entertainment on the esplanade not only performed for the benefit of the Dutch government or European nations, the colonial government also gave permission for events intended for non-European communities but Chinese, Indians and indigenous people. The celebrations that are usually carried out are Chinese New Year (Chineesch Nieuwjaar) and Indian New Year (Klingefeest) with the climax of the event holding a fireworks display on the esplanade [55]. In addition, entertainment is also held such as a night market for the general public. The night market is generally held to commemorate the birthday celebration of Queen Wilhelmina as Queen of the Netherlands. Although the entertainment and celebrations that took place on the esplanade were reserved for the colonialEuropean governments, most people could enjoy the event as spectators on the Medan city esplanade.

\section{Conclusion}

The Esplanade or what we know as the Merdeka Square today is the result of the thoughts of Deli (Delian) plantation entrepreneurs, especially the Deli-Maatshapij Company at the end of the 19th century. In accordance with the agreement Grantrechten in Deli" No.12 Resident of East Sumatra in 1891, the eslpanade was functioned as a park for the train station (stationplein) but the second decade of the 20th century turned into a public open space whose management was carried out by the Medan city government (Burgemeester en Wethouders). Not only its function as a public open space, the esplanade is seen as a central point or meeting point for the Deli plantation community in East Sumatra, and a gift from the Dutch or royal princes to the Deli pioneers as a symbol of the history of urban planning in the Dutch East Indies or called a monument. pioneer city of Medan.

Its location in the center of the city of Medan makes the esplanade a symbol of the colonial government's power which symbolizes the characteristics of modern urban areas during the colonial period. The existence of an independent field surrounding the colonial administration office indicates that the esplanade was created for the purpose of economic production and control, which at that time the city of Medan was the center of government and the center of plantation administration in East Sumatra. In addition, to build the esplanade, we use the concept of development towards the concept of images and colonial city ideas. These ideas were seen with the planting of trees at the wish of the colonial government and the physical aspects of the square such as the monuments and gates that were designed and built. The reality that was built was essentially meant to support urban culture or urban society during the colonial period. not infrequently the realities of urban life are displayed in Medan such as official, non-official, lifestyle and entertainment celebrations to make the colonial urban society a success which was managed by the colonial government. 


\section{References}

[1] Google Earth. 2021.

[2] Deli Courant. $11^{\text {th }}$ August 1939.

[3] De Sumatra Post. $10^{\text {th }}$ August 1939.

[4] Basundoro P. Dua Kota Tiga Zaman Surabaya dan Malang Sejak Kolonial Sampai Kemerdekaan, Yogyakarta: Ombak; 2009. 170.

[5] Sinar TL. Sejarah Medan Tempoe Doloe. Medan: Perwira Book; 2005. 54.

[6] Perret D. Kolonialisme dan Etnisitas; Batak dan Melayu di Sumatra Timur Laut. Jakarta: Kepustakaan Populer Gramedia; 2010. 277.

[7] Harahap A. Voor Indiers: Sejarah Kehidupan Sehari-hari Orang India di kota Medan Abad Ke-20. Yogyakarta: UGM; 2014.

[8] Loderichs MA, et al. Medan; Beeld van een Stad. Purmerend: Asia Maior; 1997.

[9] Kitlv.nl. No. 111120.

[10] Kitlv.nl. No. 111125.

[11] Leandha M. Pohon Trembesi Berumur 150 Tahun di Medan Tumbang. Available from: https://regional.kompas.com/read/2017/01/09/18460811/pohon.trembesi.berumur.150.tahun.di.med an.tumbang?page $=$ all [Accessed $30^{\text {th }}$ Juny 2021].

[12] Het Nieuws Van den Dag Voor Ned-India, $28^{\text {th }}$ December 1939. p. 5.

[13] Collectienederland.nl, TM-10015135.

[14] Collectienederland.nl, TM-60012513.

[15] Collectienederland.nl, RV A-123-1-10.

[16] Collectienederland.nl, RV A-123-1-10.

[17] Wie TK. Plantation Agriculture and Export Growth an Economics History of East Sumatra; 18631942. Jakarta: LEKNAS-LIPI Book; 1977.

[18] Sinar TL. Sejarah Medan Tempoe Doloe. Medan: Perwira; 2001. 65.

[19] Augusta. De Witnatuur En Menschen In Indië. Amsterdam: Maatschappij Voor Goede En Goedkoope Lectuur; 1914.

[20] Kitlv. nl. No.181909.

[21] Kitlv. nl. No. 14102.

[22] Ivans. Slinksche Wegen Een Roman Uit Het Delische Plantersleven. Dutch: Gravenhage D. A. Daamen's: N.VAuthor; 1938.

[23] Veersema H. Delianen Van De Tafelronde. Medan: Uitgevers Köhler S Co; 1936.

[24] Amsterdam-Batavia Per K. L. M, firma G. W. den Boer - Middelburg.

[25] Collectienederland.nl, TM-10015049.

[26] Deli Courant. 23 ${ }^{\text {th }}$ July 1938. p. 2.

[27] Algemeen Handelsblad van Woensdag. 30 ${ }^{\text {th }}$ August 1939. p. 10.

[28] De Sumatra Post. $10^{\text {th }}$ August 1939.

[29] De Sumatra Post. $4^{\text {th }}$ August 1939. p. 1.

[30] Het Nieuws Van Den Dag Vook Ned.Ïndië. 26 ${ }^{\text {th }}$ August 1939.

[31] Het Nieuws Van Den Dag Vook Ned.Ïndië. $28^{\text {th }}$ December 1939.

[32] Setiawan I. Perayaan Dua Puluh Lima Tahun Pemerintahan Ratu Wilhelmina (1898-1923) di Karesidenan Besoeki: Pesta Rakyat, Budaya Foto dan Kuasa Kolonial. Available from: https://matatimoer.or.id/2021/04/04/ [Accessed 30 th Juny 2021].

[33] Deli Courant. 16 $6^{\text {th }}$ August 1904.

[34] Collectienederland.nl, TM-60039677.

[35] Collectienederland.nl, TM-60023291.

[36] Gemeente Vlissinge. Michiel de Ruyter. Available from: https://www.vlissingen.nl/english/welcome/the-city/history/michiel de-ruyter.html [Accessed $30^{\text {th }}$ Juny 2021].

[37] Collectienederland.nl, TM-10025074.

[38] Collectienederland.nl, TM-10025075.

[39] Collectienederland.nl, TM-10025077.

[40] Collectienederland.nl, TM-10025079. 
[41] Collectienederland.nl, TM-30027595.

[42] Collectienederland.nl, TM-30027598.

[43] Collectienederland.nl, TM-30027593.

[44] Collectienederland.nl, TM-60027997.

[45] De Sumatra Post. 30 ${ }^{\text {th }}$ August 1905.

[46] De Sumatra Post. $18^{\text {th }}$ August 1922.

[47] De Sumatra Post. 24 $4^{\text {th }}$ January 1924.

[48] Kitlv.nl, No. 35943.

[49] Collectienederland.nl, TM-30047260.

[50] De Sumatra Post. 30 ${ }^{\text {th }}$ August 1905.

[51] Deli Courant. 16 ${ }^{\text {th }}$ August 1910.

[52] Deli Courant. 11 $1^{\text {th }}$ November 1910.

[53] Deli Courant. 14 ${ }^{\text {th }}$ December 1910.

[54] De Sumatra Post. $28^{\text {th }}$ June 1939.

[55] De Indische Courant. $1^{\text {st }}$ March 1928. 